\title{
The System of Management Accounting Information
}

\section{to Support Decision Making in Business}

\author{
Dam Bich $\mathrm{Ha}^{1}$, Dam Gia Manh ${ }^{1} \&$ Doan Van Anh ${ }^{1}$ \\ ${ }^{1}$ Thuong Mai University, Hanoi, Vietnam \\ Correspondence: Dam Bich Ha, Thuong Mai University, Hanoi, Vietnam.
}

Received: September 20, 2017

Accepted: October 31, 2017

Online Published: November 20, 2017

doi:10.5430/afr.v7n1p99

URL: https://doi.org/10.5430/afr.v7n1p99

\begin{abstract}
Strategy planning for competitive advantage and high effectiveness is always a target of every corporation. Nowadays, in times of wider and deeper international integration in the economy, along with industrialization and modernization, establishing and installing an information system which supports Vietnamese corporations in operation and decision-making has become pressing and necessary. Despite of successes in using the information system to make business decisions for a few years, Vietnamese corporations need to solve matters to improve it.

The article deals with basic theoretical matters of the information system in decision-making support and the fact of using it in Vietnam. It has also analyzed, evaluate the strengths and weaknesses of establishing an information system in business decision-making support, suggest Vietnamese corporation's models and solutions promote the system aiming to competitiveness and effectiveness in business.
\end{abstract}

Keywords: Competitiveness, Information System, Integration, Decision Making Support, Model

\section{Set Issue}

In the trend of globalization, business activities show more and more diversified, complex and drastic competitiveness. Therefore, the demand for information for decision making of business executives becomes important and urgent.

Information provided by management accounting is essential, direct and frequent to managers in order to make final decisions about business operations, to ensure the business survives and constantly develops in a competitive market economy. The existence of management accounting over the past decades has shown its need and importance. Nowadays, management accounting really becomes a scientific tool helping managers perform well in planning, organizing, controlling and evaluating business activities.

Today, in Vietnam, awareness and application of management accounting are still at an early stage. In reality, many people have simply understood the concept of "accounting", only mentioned the financial accounting without management accounting although the corporate accounting system has had certain manifestations of management accounting.

Vietnam's accession to the world's trade and economic organizations requires the activities of enterprises to develop more and more strongly, diversely and abundantly. In order to meet the needs of such fast progress, accounting work in enterprises must also be considered, adjusted and adapted to become more improved. On the other hand, manual information systems in enterprises also need evaluating to be gradually replaced by information systems which are automatically processed by computer ones. The rapid growth in the economy has created many changes in accounting. The work of the management accountants must find ways to establish a suitable database as well as have a flexible accounting management system to meet the current practical needs, which are providing management accounting information for administrator to make investment decisions.

\section{Overview of Research Situation}

In the world and in Vietnam, there have been many research works referred to accounting information as well as accounting information system by the authors to meet the needs of financial as well as business management, therefore develop this information to build a complete accounting information system meeting the information needs of the administrator. Specifically: 


\section{General study on composition, structure of accounting information system}

Nguyen Huu Dong (2012) - Ph.D. Thesis "Improving Accounting Information System in Vietnam's Public Universities", introduced the structure of accounting information system in non-business units, including: accounting apparatus, technical means (hardware, software, voucher system, accounts, accounting books, and accounting records system).

Huynh Thi Hong Hanh (2015) - PhD thesis "Analysis and design of accounting information systems in public hospitals" designed the accounting information system to meet the professional cycle of public hospitals in Vietnam, which is: the supply cycle, medical examination and treatment, hospital fees and finance, code design for objects, structure of database files and the relationship among databases in public hospitals.

Hall, JA, \& Bennett, PE (2011) in the book Introduction to Accounting Information Systems provided the elements of the accounting information system comprising three basic components: daily business processing system such as reports, related documents, ledger system, general financial reports and management reporting system for specific purposes such as making decisions, budget planning and making responsibility reports, ... Therefore, accounting information system is composed of data, data processing and reporting systems, providing accounting information, including financial accounting and international economic information for internal and external users.

In the study of Gelinas, U., Dull, R., \& Wheeler, P. (2011) the accounting information system in enterprises consists of 11 basic elements: database, reports, information control, business activities, management decision making, activity development system, information transmission, accounting procedures and methods. The composition of the accounting information system therefore has more elements of the administrative function than the accounting information system. It is the flow of data in the unit rather than the components of the accounting information system.

The studies on the composition and structure of the accounting information system can be seen from this view. The authors of the study of the accounting information system are divided into viewpoints: The accounting information system following the cycles of of profession and the accounting information system following the component part of it. The views of the business profession are appropriate and applicable to specific types of enterprises. The accounting information system accesses in the direction that the components are more widely applicable due to the adaptability and suitability for all types of enterprises.

Le Thi Hong (2016) - PhD thesis "Improving the cost management accounting information system in Vietnam's stone exploiting and processing enterprises" presented the viewpoint and demand of completing the system as well as systematize solutions to complete the cost management accounting information system of Vietnam's stone exploiting and processing enterprises [6]. Based on limitations and inadequacies, the authors base of the theoretical framework of the cost accounting management information system at these enterprises to propose solutions to complete the cost management accounting information system at stone exploiting and processing enterprises in Vietnam.

Matej Spanja, Iva Tokic, Ivana Blazevic (2011) point out that the general procedure of the accounting information system started with the process of collecting data inside and outside the unit, combined with the available database in the system for analysis and process in accordance with accounting standards, policies, methods and recording tools for obtaining accounting information to provide information to the users.

Agreeing with the above viewpoints, Senin's (2011) showed that the accounting information system process within the unit involves the process of collecting, calculating, storing, analyzing, reporting and managing information. In enterprise accounting information system, there are two subsystems: the financial accounting information system and the management accounting information system, in which the second provides information to internal users and the first provides information to external ones. Hall, JA, \& Bennett, PE (2011) also argued that the procedure of the accounting information system was started from financial and nonfinancial profession via the accounting information processing system for the user to make decisions.

Thus, on the general procedure of accounting information system, both domestic and foreign authors agree that the accounting information system has a common process starting from information collecting, processing and analysis with identified methods and procedures, therefore provide information to the users.

\section{Study on the application of technical means in the accounting information system}

In Vietnam, Nguyen Bich Lien (2012) - PhD thesis "Identifying and controlling the factors affecting the quality of accounting information in the enterprise resource planning system environment in Vietnamese enterprises" has shown a viewpoint on the impact of applying information technology on the quality of accounting information, especially integration software ERP: The information provided is more diverse, processing and providing speed is 
faster and more timely for the administrator and ensure the accuracy of the provided information.

In her study, Lili Zhao (2015) conducted a research accounting information system on a computer in the condition of network application. Research has shown that in computerized conditions, the entire process of data processing, processes, accounting methods and data storage have changed. In terms of technology development, the computerization of accounting work is inevitable, using technology in processing accounting information has significantly improved the quality of accounting information.

In their article, Ladewi, Yuhanis (2014) studied on the purpose of looking at administrative change and management commitment to the implementation of ERP and the impact on the quality of accounting information. The ERP system was a computer system allowing the management of resources in the enterprise overall. The results showed that there was considerable influence of management commitment and administrative change to implement the ERP system and indirectly affect the quality of accounting information. Meanwhile, there was a close relationship between management and management commitment to the implementation of the ERP system, with the quality of information provided.

Thus, the above studies suggest that the use of the resource planning system in the unit is the appropriate choice for the development of the synchronous accounting information system in the enterprise. Using this system has proven effective in businesses.

\section{Objectives and Research Methods}

The objective of this article is to investigate the application of management accounting information system for business decision making. Therefore, we can draw on its successes, limitations and causes to have more realistic solutions to promote the application of decision support information system for Vietnamese enterprises in the coming time.

In order to complete this study, the author has applied research methods used such as statistics, data synthesis, types of materials for comparison, analysis, evaluation, risk forecasting, the effect of raising funds for infrastructure development.

At the same time, the author collects and synthesizes the materials on the research works in the world and in Vietnam, which has been announced so far involved in the process of raising capital for infrastructure investment development to summarize, analyze and compare research results of each project to see the achievements and unsuccessful points, thus determine the research objectives. Specifically, the research methods used by the author in this article are as follows:

Firstly, Method of data and information collection:

Secondary information collection method: The topic of analysis of previous studies on accounting information system in general and management accounting information system in particular. In addition, the author also researches scientific topics at all levels, many scientific articles, presentations, some $\mathrm{PhD}$ thesis research on accounting information system.

Primary data collection method: The author conducts in-depth interviews. Once the navigation information is available, the data needs surveying and collecting. The author interviews a number of accountants and managers of enterprises to see the importance of management accounting information systems in the enterprise as well as its role in making investment decisions.

Secondly, the method of synthesis and processing information

- Secondary information and materials are arranged according to each research topic and divided into 3 groups: an overview of the research situation, an overview of the accounting information system and support decision making to propose a solution to promote the application of information systems to support decision-making for Vietnamese enterprises in the coming time.

- Information analysis methodology: All primary data collected from in-depth interviews will be analyzed by comparison control and expert method.

\section{Overview "Management Accounting Information System Supporting Decision-making"}

It can be briefly described, "Management accounting information systems are a collection of human, facilities, financial and non-financial information that work together to collect, process and provide information to the administrator ".

Management Accounting Information System and Financial Accounting Information System are two modules of the Accounting Information System. Management accounting information system includes the typical subsystems such as cost accounting and product costing; sales accounting and business results; analyze the relationship between cost, volume and profit; select the appropriate information for decision-making, product budget estimation for business. 
Management accounting information system is collected and processed to have the necessary and useful accounting information provided to the administrator. The result of the use of this accounting information is that new accounting decisions and actions are taken.

The management accounting information system is responsible for providing information for the planning and budgeting process; for the implementation process; in the process of auditing, evaluating and, above all, for the decision-making process.

Decision-making is not a separate function, but a combination of all three functions: planning, organizing implementation and evaluating. All of them require a decision. Most management accounting information serves the decision-making function. Management accounting not only helps managers in decision-making by providing the right information, but also by applying analytical techniques to different situations, from which executives chooses and makes the most appropriate decision.

\section{Application Situation of Decision Support Information System in Organizations and Vietnamese Enterprises}

\subsection{General Overview of the Current Application of Decision Support Systems in Vietnamese Organizations Today}

At present, the application of decision support systems in organizations and enterprises in Vietnam has gradually been considered and shown their roles and benefits. However, to be able to apply and replicate this system in the enterprise is not easy, because each business has different ways of operating and demand. Therefore, not all systems meet these requirements. On the other hand, there are not many systems in this market and prices are not low. These are some of the difficulties facing the business when it comes to apply decision support systems to managers.

In Vietnam, there are various fields of activity that have used decision support systems, especially, have been applied by the State to natural resource and environmental projects. Some successful systems have been used, such as the Remote Sensing Application and Geographic Information System Project in the design of the Forest Management Board's five-year forest management planning decision support system of Bo River Watershed Protection (Center for Natural Resources and Environment in collaboration with Forest Inventory and Planning Institute, 2005); Introduce the experience in developing and applying DSS tools in water resources management (showing the challenges facing management and feasibility studies in Vietnam by the Institute of Hydro-meteorological Sciences and Environment in cooperation with DHI Group held in 2011); The IWRM-Vietnam Water Resources Research Project, the overall water resource management, provides subprojects with the objective of developing methods to support decision-making for IWRM work through cooperation with competent relevant authorities in Vietnam.

Many large Vietnamese companies have implemented decision support systems in their management activities, resulting in high efficiency, including the Kinh Do Company. In 2010, Kinh Do's promotions, advertisement and branding activities were more focused and effective thanks to the introduction of the customer information collection system and the analysis of business results. In addition, the company also boldly buys market information of the world's leading companies.

The current situation of application of decision support system in Vietnamese organizations and enterprises shows that:

The level of use of information and computer systems to support decision-making by businesses is low (about 50\% of businesses use it); even businesses have never used computers to support the decision-making process in the course of their business. From this we can say that the application of information systems in decision-making in Vietnamese enterprises is still very limited and needs implementing more widely.

Most managers make decisions based on their own experience, and they rely on the return that the company makes when making those decisions. Quite a few leaders know models and decision-making algorithms. So how to put them into decision support systems to help managers make the most effective decisions, but still easy to use is the problem set in our country today.

It can be seen that the majority of decisions made in the enterprise are by senior and middle management. Therefore, the decision support system will serve these people. However, one problem is that managers often do not have much time to update new technologies and apply them to their management activities. Therefore, there is a need for appropriate and reliable support systems that will help them.

Decision support systems are highly appreciated and bring many benefits to the business when it is used such as helping managers make decisions quickly and accurately, increasing their competitiveness with competitors, making the right decisions, thereby increasing the confidence of investors as well as enhancing the image of the business. Businesses pay special attention and to the decision support system. In addition, they all find that decision support 
systems are very useful for managerial decision-making. However, very few enterprises implement the system in the enterprise.

\subsection{The Situation of Application of Management Accounting Information System Support Decision-making}

In Vietnam, management accounting has also emerged, developed along with the accounting policies and regimes applied in enterprises, however, it was only systematically dealt with in the early 1990s and became an urgent requirement in the development of accounting information systems in the early 2000s when businesses needed to improve the quality of management to increase competitiveness in the competitive environment, not only in the Vietnamese market but also in the regional and world market

Legally, the term "management accounting" has just been officially recognized in the Vietnamese Accounting Law issued on 17 May 2003.

When studying the Vietnamese Accounting Law and the Ministry of Finance's Circular No. 53/2006 / TT-BTC dated June 12, 2006, guiding the application of managerial accounting in enterprises, we find that: the Accounting Law Vietnam and Circular 53/2006 / TT-BTC are only guidelines for Vietnamese enterprises when applying the management accounting information system, but there is no general legal regulation in the form and content reports. Therefore, enterprises must set up a specific system of management accounting indicators in accordance with management objectives.

Recognizing the importance of management accounting information systems in providing useful information to help managers make appropriate decisions, especially long-term investment ones, nowadays, in Vietnam, there are some studies on management accounting information systems for long-term investment decisions; many businesses have put the operation of the management accounting information system into order. It has really provided useful information for administrators, especially in three stages:

(1) The process of collecting management accounting information: Most enterprises have developed an information channel model among departments to collect information according to the specific function of each department, the information collected from internal sources.

(2) Information processing: Enterprises have developed a number of reports.

(3) Providing information process: management accounting information system for decision-making of enterprises developed specialized reports, consolidated tables, analysis indicators, selection options; meet the requirements of the administrator in decision-making.

Limitations of accounting software application management support accounting decision making in Vietnamese enterprises today:

In addition to the achieved results, in practice the management accounting information system for investment decision making in Vietnamese enterprises has limitations:

\section{(1) The organizational accounting model of some enterprises is not reasonable:}

The development of business plans and projects often involves many sources of information: external sources, internal sources, financial information, non-financial information in various fields such as information about the market, development strategy, production capacity, this information is collected from various departments involved. Meanwhile, the information section is that accountants do not have enough authority to assess the reliability of such information. The collection, process, supply of management accounting information is not complete.

Management accounting for decision-making has been established in many organizations and businesses. However, since it was introduced in the early stages, it was not really focused. Organizational accounting models of many organizations and enterprises are not organized in a scientific way, the separation of content between financial accounting and management accounting is not clear.

On the other hand, the staff of management accounting information systems in charge of decision making in some places must also cite the part of the related financial accounting showing that the accounting and management organization is very illogical.

(2) The system of analysis of management accounting information for decision making in some organizations and enterprises has not yet met the needs of the unit. For example, to evaluate the financial effectiveness of projects, some companies use a payback period. This method will result in inaccurate and inappropriate for projects with large total investment and long implementation time.

(3) Reporting system for decision making in many organizations and enterprises is not sufficient. Many businesses have built management accounting forms. However, they are lack of professionalism and standards. 
(4) The collection and processing of information to provide administrators for decision making in some organizations and enterprises is still low and the quality of information is not high. In the process of collecting information, management accountant receives information from other relevant entities, then synthesizes and uses business profession to create management reporting forms. Management accountant does not evaluate other areas of expertise, so the quality of input to the management accountant depends on the information provided by other departments.

Therefore, the quality of information provided to decision-makers is not as expected.

\section{(5) Some other limitations:}

- The level of the team doing management accounting and information systems for decision-making in many organizations and enterprises has not met the requirements well.

Because: (1) In the labor recruitment process, many organizations and enterprises do not really pay much attention to those who work in management accounting for long-term investment decision making at university level and higher; (2) The team of management accounting information for decision-making must cumulate many tasks and there are cases in which work is not in line with the professionally trained; (3) The ability of the team to apply technological information to their work is limited.

- IT equipment and machinery to handle the work are lack of modernity, the collection of information from internal sources has been established but still difficult. The number of computers serving the managers of accounting work for decision-making in many organizations and enterprises is still lacking and one person does not have their own computer to take initiative in their work. Many businesses do not currently have a LAN set up for the whole unit to collect information among administrators and departmental departments; among departments, functional departments and relevant departments; meanwhile, the Internet system is still limited, slow and discontinuous.

- The documents guiding the implementation management of accounting, using information systems for enterprises, specific forms of management accounting for decision-making are almost none.

In terms of State management, current regulations and guidelines on management accounting include the Vietnamese Accounting Law and Circular No. 53/2006 / TT-BTC issued on 12 June 2006 of the Ministry of Finance. For businesses, they built their own internal documents in line with regulations and met the management requirements, so the management accounting staff in the decision making of many businesses faced many difficulties, especially in the preparation of unified reports throughout the unit.

An investigation into the impediments to the complete the management accounting information systems for decision-making shows: (1) the level of management accounting staff (100\%); (2) lack of technological information machinery and equipment (91,30\%); (3) organizational management accounting (97.39\%); (4) internal guidelines in enterprise (13.04\%); (5) production process (9.57\%); (6) some other obstacles such as the size of the operation, the views of the executives, the management mechanism or the macro policies of the State. Some say that those reasons are obstacles to the management accounting systems for decision-making.

\section{Some Solutions to Support Information System to Support Decision Making to Vietnamese Enterprises}

\subsection{Build and Use Business Information Systems}

Information systems are now very various and diverse. The application of different information systems depends on the purpose of application, scale of operation and other conditions of each organization or enterprise. The aim of the business information system is to provide information that serves the business effectively. As with other management information systems, the business information system has the following main functions:

- Collecting, analyzing and archiving business information in a systematic way to help exploit and use useful information for business activities in the most convenient and effective way.

- Changing, correcting and supplementing information, dealing with groups of indicators, creating new information.

- Distributing and providing business information.

In general, when building and using information systems, businesses aim to: support operational activities, management decisions and construction strategies for gaining competitive advantage. Thus, a business information system, including the main following information modules and applications can be viewed:

(1) Information modules for management and administration, including:

- Subsystem of synthesis and quick report output

- Subsystem of e-mail and dispatch management

- Task Scheduler Management System 
- Subsystem to support scheduling and production management

- Website operating operations

(2) Marketing, advertising, distribution and customer service modules:

- Subsystem of sales management information

- Website introducing companies and products

- Customer forums and feedback

(3) Internal management information modules:

- Subsystem of human resource and salary management

- Subsystem of management accounting

- Subsystem of storage and product management

- Subsystem of customer and agent's management

- Subsystem of management of means of transport

(4) Building specialized databases

This set of information modules above will form a business information system. They can deploy many services for computerization of management, business and especially e-commerce due to this information. The establishment of specialized databases must ensure two purposes: firstly, to meet the needs of the units; secondly, data must be provided to the sectoral and local storage and other subsystems.

In order to build a complete business information system, attention should be paid to the following issues:

Firstly, the relationship between the business information system and the management system of the business:

The executive structure decides how the business is run. Most businesses now operate under the hierarchy, division of functions according to features. This model leads to a system of organization of the enterprise apparatus divided into specialized departments with a hierarchy of responsibilities and tasks, with specific reporting regimes and operational procedures. An information system with a primary function of collecting, processing and transmitting information, acting as an intermediary and a tool for the operation and administration, so it must follow the model that the operating structure has been chosen and must serve effectively the members of the organization.

\section{Secondly, the interactions between applications in information systems under the business information system:}

It is possible to segment the business information system into the information modules described above, but we need to see that the information modules interacting with each other, for example applications in the management module, operational management, product distribution marketing module, are the consequence of building specialized databases. We have built specialized databases to have data available to our subsystems of management, operations, marketing and distribution, and decision support. On the contrary, due to the need for management modules, operational management, product marketing and distribution modules and decision support systems, we see the need to build specialized databases.

\subsection{Develop and Use Accounting Information System for Decision-making}

\subsubsection{Information Collecting Model}

* Step 1: Identify sources of information

Management accounting information can be collected from two sources:

- Internal information sources within the organization include financial accounting books; human resource record; production tracking record.

- External sources, includes:

+ Primary source: The information from the original source itself must be collected directly from many forms such as observation, direct interview,

+ Secondary source: The secondary source of information is the source of processed information such as books, articles, reports,

* Step 2: Collect information

To get accounting information, the first job is to set up the accounting records system. All economic-financial profession arising in the production and business activities of the enterprise must make valid and lawful financial 
papers the sole basis for making entries in the accounting books.

Organizing the collection of information on accounting vouchers is a major task of building the accounting information system. The content of this work is the original accounting organization in the parts of the enterprise and organization of intragroup transactions.

Management accounting, in addition to the use of information on financial and business operations arising, is actually completed reflecting on the accounting vouchers of the compulsory document system for integrated analysis and aggregation. The detailed cost, income and results situation also uses the voucher system. The guidance documents are concreted by enterprises; according to the criteria directly serve the collection, processing and supply of information. The checking, processing and circulation of vouchers are established in a way that ensures accurate and truthful information for evaluating the implementation.

\subsubsection{Information Processing Model}

After identifying the data source and gathering input information, we can use the following methods of information processing: (1) Net Present Value method (NPV); (2) modified internal rate of return (IRR); (3) the return method; (4) modified profitability index (PI)

\subsubsection{Informational Model}

After collecting accounting information, the above methods have produced quantifiable results, based on which management accountant analyzes and evaluates investment projects and builds the reporting system to help managers make decisions on the selection of investment projects by one of the four methods mentioned above.

\subsection{Some Other Solutions}

Decision support is a difficult issue, requiring cooperation from a variety of disciplines and best planned right in the information system design. Maybe by the time and the practical needs, we will supplement the data treasure and decision support methods.

Having developed and deployed a standardized information system with a full range of specialized databases, the development of queries to meet frequently required questions to support decision-making at the leadership level... is an important and meaningful job. Some of the technical work required for decision support is: (1) standard design of data warehouse; (2) Apply algorithms, statistical methods, optimization algorithms, ... to provide optimal solutions for decision-making at the leadership level; (3) Proper use of the Data Integration Center: The Data Integration Center should be the source of data for all specialists in different professions to exploit. We should not assume that only IT specialists exploit this center.

Apart from the technical issues mentioned above, the following solutions should be implemented synchronously:

\subsubsection{Raise Awareness of the Role of Decision Support Information Systems}

Organizations and businesses need to be aware of the role of the decision support information system and the management accounting information system and soon complete management accounting system following independent model with separate financial accounting department. Based on that, management accounting in general and management accounting for decision-making and decision support information system in particular should be specialized, cost and time savings and bring more efficiency.

6.3.2 Pay Special Attention to the Training and Improvement of Professional Qualifications of Decision-making Supporters

Training and fostering the staff of accounting management and management accounting information system with deep knowledge of accounting profession and related subjects such as: management, economic analysis, statistics, skills in making specific reports of management accounting as well as knowledge of decision support information systems. Specifically:

Firstly, professional qualifications:

- For those who have been doing management accounting, information systems for decision-making:

+ Every year, organizations and enterprises must have fostered plans to upgrade their qualifications and grasp timely documents to operate on specific tasks in enterprises.

+ Require the team of management accounting, information system support decision often study to improve professional qualifications.

- For those who will apply to work:

+ Priority for students at the National Economics University: Academy of Finance - Accounting; Thuong Mai 
University, which are majors that organizations and businesses need.

+ Those who have experience in working with a specialized major in other units, want work in organizations and enterprises.

Secondly, enhance the applicability of information technology

- Require $100 \%$ of the management accounting staff to know how to use the computer and know how to access the Internet to update, exploit and make good use of information in the field for their work.

- Enterprises must have study plans to improve the applicability of information technology to the team of management accounting, access to accounting software and modern decision support one.

\subsubsection{Regularly Invest In New Purchase, Upgrade Computer System and Make Good Use of LAN}

- Investing in the purchase of computers for managers in charge of making decisions to meet 1 person with 1 computer to take the initiative in their work, and effectively uses working time; for slow-speed computers, investment needs to be upgraded to meet the requirements of use.

- Organizations and enterprises need to set up a LAN for the whole unit so that the information-gathering department can perform smoothly and get the requests of the administrators, coordinate with other departments and the accounting department of the subordinate units.

- Organize the application of information technology in the collection, processing and supply of economic management information to help making long-term investment decisions become simple, save labor and time, gather information from multiple sources, ensure reliability to analyze and handle more accurate information, meet the requirements of executives in making decisions to make long-term investment quickly and in time.

6.3.4 Develop and Use Collect, Process and Provide the Information Model for Decision Making to Meet the Requirements

- For the process of collecting information: the management accounting department in addition to collecting information from the original documents and the relevant departments, they need to collect information from those of the unit members to ensure the reliability of information.

- For information processing: Software should be equipped with advanced information processing models for decision-making.

- For the process of providing information, instead the information system department reports the management by direct submission of documents, In addition to submitting documents directly to the administrator to provide timely information, we can send information by email, so that the administrator can update information whenever, anywhere.

\section{Conclusion}

Nowadays, the decision support system has become popular with not only organizations and enterprises in the world, but also in Vietnam. The application of these systems has confirmed the practical effect as well as brings long-term benefits for organizations, enterprises in general and managers in particular.

The article focuses on the models used in decision support information systems, the role of the system in the enterprise as well as the current situation of system application in Vietnam.

The article can help organizations and enterprises choose the decision-making methods to support the decision-making of managers, enhance the value of the decision of the organization or enterprise.

At the same time, it is also a useful material for the training of the "Information System Administration" of the Thuong Mai University, as study materials, scientific research for students, $\mathrm{PhD}$ student.

The application of decision support systems is now essential for all organizations and businesses. However, for those to understand the benefits of these systems and invest capital is not easy. Therefore, it is necessary to have the appropriate route and solution to convince the manager to use this system.

Managers also need to innovate their thinking and working methods, learn new knowledge, which can be applied to their decision making, to improve the performance of their organizations.

\section{References}

Development strategy of information technology and communications to 2010, orientation to 2020. Ministry of Posts and Telecommunications.

Documents and reports on information and communication technology in Vietnam of National Steering Committee on information technology, VNCI, Ministry of Commerce, Ministry of Education and Training. 
Field, Mike \& Laurie Keller. (1998). Project Management, London, International Thomson Business Press.

Gelinas, U., Dull, R., \& Wheeler, P. (2011). Accounting information systems. Cengage learning.

Hall, J. A., \& Bennett, P. E. (2011). Introduction to Accounting Information Systems. South-Western Cengage Learning.

Hertati, L., \& Zarkasyi, H. W. (2015). Effect of competence user information system, the quality of accounting systems management and implications insastisfaction user information system (State owner in Sumatera Selatan). European Journal of Accounting, Auditing and Finance Research, 3(2), 35-60.

Huynh Thi Hong Hanh. (2015). PhD thesis "Analysis and design of accounting information systems in public hospitals"

John J. Rakos. (1990). Software Project Management for Small to Medium size Projects. Prentice Hall.

Ladewi, Yuhanis. (2014). Influence of chance management and management commitment on implementation of ERP system \& its impact on quality of accounting information -a survey of burn companies in Bandung. International Journal of Economics, Commerce and Management United Kingdom, II(9).

Le Thi Hong. (2016). PhD thesis "Improving the cost management accounting information system in Vietnam's stone exploiting and processing enterprises"

Marakas, GM. (1999). Decision support systems in the twenty-first century, Upper Saddle River, NJ, Prentice Hall.

Marija Tokic, mateo, Iva tokic, Ivona Blazevic. (2011). Functional structure of enterpreneurial accounting information systems, Annals of faculty Engineering Hunedoara. International Journal of Engineering, Tome IX.

Nguyen Huu Dong. (2012). Ph.D. Thesis "Improving Accounting Information System in Vietnam's Public Universities".

P. Cowhey, M. Kleeman. (2012). Unlocking the Benefits of Cloud Computing for Emerging Economies: A Policy Overview, University of California, San Diego.

P.D. Hamerman, L. Herbert, C. Andrews, A. Ephraim. (2015). Application Adoption Trends 2015: The SaaS Boom Continues As Businesses Demand Agility, Forrester Research Inc..

Report on the socio-economic situation in 2014 and the tasks of 2015 presented by Nguyen Tan Dung Prime Minister at the 8th session of the XIII National Assembly, October 20, 2014.

Report on the readiness for information and communications technology development and application

(Viet Nam ICT Index) 2014 of Vietnam Association for Information Processing; Office of National Steering Committee on information technology and Ministry of Posts and Telecommunications in Ha Long on August/2014.

Ronald W.Hilton. (1998). Managerial Accounting, Grall, Inc.

Senin. (2011). The Purpose of Management Accounting Information and The Process of Management Accounting.

White book on Vietnamese Information Technology and Communications in 2014- Information and Communications Publishing House - 2014. 